\title{
PENGARUH KOMPETENSI DAN MOTIVASI KERJA TERHADAP KUALITAS LAPORAN KEUANGAN \\ (Studi Pada Badan Keuangan dan Aset Daerah Kabupaten Muna)
}

\author{
Oleh \\ Santiadji Mustafa ${ }^{1}$, Hasbudin ${ }^{2}$, Halmatinus ${ }^{3}$ \\ Jurusan Akuntansi Fakultas Ekonomi dan Bisnis Universitas Halu Oleo Kendari \\ Sulawesi Tenggara
}

\begin{abstract}
ABSTRAK
Penelitian ini bertujuan untuk menguji pengaruh kompetensi dan motivasi kerja terhadap kualitas laporan keuangan. Pengumpulan data dilakukan dengan cara menyebarkan kuesioner kepada pegawai pada Badan Keuangan dan Aset Daerah Kabupaten Muna yang terdiri dari 20 responden. Teknik pengambilan sampel menggunakan metode purposive sampling. Metode analisis yang digunakan adalah analisis deskriptif dan analisis regresi linear berganda.

Hasil penelitian ini menunjukan bahwa variabel kompetensi dan motivasi kerja secara parsial berpengaruh positif dan signifikan terhadap kualitas laporan keuangan pada BKAD Kabupaten Muna. Sedangkan koefisien determinasi menunjukkan hasil bahwa secara simultan pengaruh yang diberikan variabel kompetensi dan motivasi kerja terhadap kualitas laporan keuangan sebesar 58\% dan sisanya sebesar $42 \%$ yang dipengaruhi oleh variabel lain yang tidak diteliti dalam penelitian ini.
\end{abstract}

Kata kunci : Kompetensi, Motivasi Kerja, Kualitas Laporan Keuangan

\section{ABSTRACT}

This study aims to examine the effect of work competence and motivation on the quality of financial statements. Data collection was carried out by distributing questionnaires to employees at the Muna Regency Regional Financial and Asset Agency consisting of 20 respondents. The sampling technique uses purposive sampling method. The analytical method used is descriptive analysis and multiple linear regression analysis.

The results of this study indicate that the variables of work competency and motivation partially have a positive and significant effect on the quality of financial reports in BKAD Muna Regency. While the coefficient of determination shows the result that the simultaneous influence of the competency and work motivation variables on the quality of financial statements is $58 \%$ and the remaining $42 \%$ is influenced by other variables not examined in this study.

Keywords: Competence, Work Motivation, Quality of Financial Statements

\section{PENDAHULUAN}

Perubahan sistem penyelenggaraan pemerintah daerah dari sentralisasi ke desentralisasi mendorong diberlakukannya otonomi daerah. Otonomi daerah adalah hak, wewenang, dan kewajiban daerah untuk mengatur dan mengurus pemerintahan daerah sesuai dengan peraturan perundang-undangan. Berlakunya otonomi daerah maka pengelolaan keuangan sepenuhnya berada di pemerintah daerah. Amanat Undang-Undang Nomor 23 Tahun 2014 tentang Pemerintah Daerah yang menyatakan bahwa penyerahan kewenangan pengelolaan keuangan kepada daerah menimbulkan tuntutan besar masyarakat kepada pemerintah daerah untuk menyelenggarakan pemerintahan yang baik (good governance). 
Laporan keuangan merupakan produk akhir dari proses akuntansi yang telah dilakukan. Laporan keuangan adalah suatu hasil dari proses pengidentifikasian, pengukuran, pencatatan dari transaksi ekonomi (keuangan) dari entitas akuntansi yang ada dalam suatu pemerintah daerah yang dijadikan sebagai informasi dalam rangka pertanggungjawaban pengelola keuangan entitas akuntansi dan pengambilan keputusan ekonomi oleh pihak-pihak yang memerlukannya. Peraturan Pemerintah Nomor 71 Tahun 2010 Tentang Kerangka Konseptual Akuntansi Pemerintahan, Paragraf 35-40 menyatakan bahwa karakteristik kualitatif laporan keuangan adalah ukuran-ukuran normatif yang perlu diwujudkan dalam informasi akuntansi sehingga dapat memenuhi tujuannya. Keempat karakteristik berikut ini merupakan prasyarat normatif yang diperlukan agar laporan keuangan pemerintah dapat memenuhi kualitas yang dikehendaki terdiri dari : 1) relevan, 2) andal, 3) dapat dibandingkan, 4) dapat dipahami.

Proses pelaporan keuangan pemerintah harus dikerjakan oleh sumber daya manusia yang memiliki kompetensi agar mampu menyusun dan menyajikan Laporan Keuangan Pemerintah Daerah yang berkualitas. Wibowo (2014) menyatakan bahwa kompetensi adalah suatu kemampuan untuk melaksanakan atau melakukan suatu pekerjaan atau tugas yang dilandasi atas keterampilan dan pengetahuan serta didukung oleh sikap kerja yang dituntut oleh pekerjaan tersebut. Kompetensi juga menunjukkan karakteristik pengetahuan dan keterampilan yang dimiliki atau dibutuhkan oleh setiap individu yang memampukan mereka untuk melakukan tugas dan tanggung jawab mereka secara efektif dan meningkatkan standar kualitas profesional dalam pekerjaan mereka.

Pentingnya kompetensi sumber daya manusia bagi sebuah lingkungan kerja, maka instansi pemerintah harus dapat mempertahankan kompetensi tersebut. Sehingga diperlukan motivasi kerja berupa penghargaan, bonus, ataupun spirit yang diberikan oleh pimpinan dalam rangka mempertahankan kinerja yang baik dan meningkatkan kualitas pegawai agar lebih bersemangat dalam bekerja atau menyelesaikan pekerjaan tepat waktu.

Beberapa peneliti sebelumnya telah melakukan penelitian dan menyatakan bahwa kompetensi dan motivasi kerja memiliki pengaruh terhadap kualitas laporan keuangan, namun ada juga yang menyatakan tidak berpengaruh. Ketidakkonsistennya hasil yang diperoleh dari beberapa peneliti sebelumnya menimbulkan adanya research gap. Penelitian mengenai kompetensi terhadap kualitas laporan keuangan telah diteliti sebelumnya oleh Ela Margalina (2013), Henny Evita Minaruly Gultom (2016), Nurillah (2014), Athikah Fathinah Putri (2014) yang menyatakan kompetensi berpengaruh dan signifikan terhadap kualitas laporan keuangan. Penelitian mengenai motivasi kerja terhadap kualitas laporan keuangan telah diteliti sebelumnya oleh Athikah Fathinah Putri (2014) yang menyatakan motivasi kerja tidak berpengaruh terhadap kualitas laporan keuangan.

Berdasarkan Laporan Hasil Pemeriksaan Badan Pemeriksa Keuangan (BPK) pada Pemerintah Kabupaten Muna diperoleh informasi bahwa pengelolaan keuangan daerah Kabupaten Muna tahun 2011-2015 berhasil meraih opini Wajar Dengan Pengecualian (WDP). Setelah sebelumnya pada tahun 2008-2010 mendapat opini Tidak Memberikan Pendapat (TMP) (Sumber : Ikhtisar Hasil Pemeriksaan Semester I dan II tahun 2015). Hal ini menunjukkan tidak adanya perubahan atau peningkatan opini BPK terhadap laporan keuangan Pemerintah Daerah Kabupaten Muna dalam kurun waktu tersebut.

Tabel 1. Opini BPK atas Laporan Keuangan Pemerintah Kabupaten Muna

\begin{tabular}{|l|l|l|}
\hline No & \multicolumn{1}{|c|}{ Tahun } & \multicolumn{1}{c|}{ Opini BPK } \\
\hline 1 & 2013 & Wajar Dengan Pengecualian (WDP) \\
\hline 2 & 2014 & Wajar Dengan Pengecualian (WDP) \\
\hline 3 & 2015 & Wajar Dengan Pengecualian (WDP) \\
\hline 4 & 2016 & Wajar Tanpa Pengecualian (WTP) \\
\hline 5 & 2017 & Wajar Tanpa Pengecualian (WTP) \\
\hline
\end{tabular}


Namun pada tahun 2016 hingga 2017 mengalami peningkatan opini terhadap Pemerintah Kabupaten Muna mendapatkan opini Wajar Tanpa Pengecualian (WTP). Hal inilah yang menjadikan ketertarikan peneliti untuk mengetahui lebih jauh mengenai keberhasilan yang dicapai pemerintah kabupaten muna dalam mempertahankan opini WTP.

Peningkatan opini yang berhasil dipertahankan oleh Pemerintah Kabupaten Muna merupakan kerja keras tim penyusun LKPD dan semua aparatur pemerintah daerah, dengan melakukan berbagai pelatihan-pelatihan di bidang pengelola keuangan, serta peran audit internal yang berkaitan langsung dengan kualitas laporan keuangan dalam pengelolaan keuangan dan tanggung jawab keuangan daerah. Prioritas Pemerintah Kabupaten Muna saat ini salah satunya yaitu mengenai peningkatan kompetensi sumber daya manusia. Sehingga diharapkan pihak pengelola keuangan daerah khususnya bagian akuntansi mampu melaksanakan tugas dan fungsi akuntansi dengan baik sehingga prestasi opini wajar tanpa pengecualian akan terus di pertahankan dan semakin ditingkatkan sesuai dengan peraturan perundang-undangan yang berlaku.

Tujuan dalam penelitian ini adalah (1) Mengetahui dan menganalisis pengaruh kompetensi terhadap kualitas laporan keuangan pada BKAD Kab. Muna. (2) Mengetahui dan menganalisis pengaruh motivasi kerja terhadap kualitas laporan keuangan pada BKAD Kab. Muna. (3) Mengetahui dan menganalisis pengaruh kompetensi dan motivasi kerja berpengaruh secara simultan terhadap kualitas laporan keuangan BKAD Kab. Muna.

\section{TINJAUAN PUSTAKA}

Peraturan Pemerintah No. 71 Tahun 2010 menyatakan bahwa laporan keuangan merupakan laporan yang terstruktur mengenai posisi keuangan dan transaksi-transaksi yang dilakukan oleh suatu entitas pelaporan. Dalam sebuah lembaga pemerintah dituntut untuk membuat laporan keuangan eksternal yang meliputi laporan keuangan formal seperti laporan surplus defisit, laporan realisasi anggaran, laporan arus kas, dan neraca serta kinerja yang dinyatakan dalam ukuran finansial dan non finansial. Berdasarkan Peraturan Pemerintah Nomor 71 Tahun 2010, tentang Standar Akuntansi Pemerintahan (SAP), komponen-komponen yang terdapat dalam satu set laporan keuangan yang berbasis akrual terdiri dari pelaksanaan anggaran dan laporan finansial, yang terdiri dari: Laporan Realisasi Anggaran, Laporan Perubahan Saldo Anggaran Lebih, Laporan Operasional, Laporan Perubahan Ekuitas, Neraca , Laporan Arus Kas, Catatan Atas Laporan Keuangan.

Menurut Kepala Badan Kepegawaian Negara Nomor 46 A Tahun 2003 yang menyatakan bahwa kompetensi adalah kemampuan dan karakteristik yang dimiliki oleh seorang pegawai negeri sipil berupa pengetahuan, keterampilan, dan sikap perilaku yang diperlakukan dalam pelaksanaan tugas jabatannya, sehingga dapat melaksanakan tugasnya secara profesional, efektif, dan efisien. Menurut Hutapea dan Thoha (2008), mengungkapkan bahwa ada tiga komponen utama pembentukan kompetensi yaitu sebagai berikut :

1. Pengetahuan (knowledge) adalah informasi yang dimiliki seseorang karyawan untuk melaksanakan tugas dan tanggungjawabnya sesuai bidang yang digelutinya. Misalnya bahasa komputer, pengetahuan turut menentukan berhasil tidaknya pelaksanaan tugas yang diberikan.

2. Keterampilan (skill) adalah suatu upaya untuk melaksanakan tugas dan tanggung jawab yang diberikan perusahaan dengan baik, disamping itu pengetahuan dan kemampuan karyawan, hal yang paling perlu diperhatikan adalah sikap perilaku karyawan.

3. Sikap (attitude) adalah pola tingkah laku seseorang karyawan di dalam melaksanakan tugas dan tanggung jawabnya sesuai dengan peraturan perusahaan. 
Motivasi kerja merupakan motivasi yang terjadi pada situasi dan lingkungan kerja yang terdapat pada suatu organisasi atau lembaga. Pada dasarnya manusia selalu menginginkan hal yang baik-baik saja, sehingga daya pendorong atau penggerak yang memotivasi semangat kerjanya tergantung dari harapan yang akan diperoleh mendatang jika harapan itu menjadi kenyataan maka seseorang akan cenderung meningkatkan motivasi kerjanya. Menurut Siagian (2008), mengungkapkan bahwa ada tiga komponen utama pembentukan motivasi kerja, yaitu :

1. Kebutuhan adalah kebutuhan timbul dalam diri seseorang apabila orang tersebut merasa ada kekurangan dalam dirinya. Menurut pengertian homeostatic, kebutuhan timbul atau diciptakan apabila dirasakan adanya ketidakseimbangan antara apa yang dimiliki, baik dalam arti fisiologis maupun psikologis.

2. Dorongan adalah usaha untuk mengatasi ketidakseimbangan biasanya menimbulkan dorongan. Hal tersebut merupakan usaha pemenuhan kekurangan secara terarah yang berorientasi pada tindakan tertentu yang secara sadar dilakukan oleh seseorang yang dapat bersumber dari dalam maupun dari luar diri orang tersebut.

3. Tujuan adalah segala sesuatu yang menghilangkan kebutuhan dan mengurangi dorongan. Mencapai tujuan, berarti mengembalikan keseimbangan dari dalam diri seseorang, baik bersifat fisiologis maupun bersifat psikologis.

\section{Paradigma Penelitian}

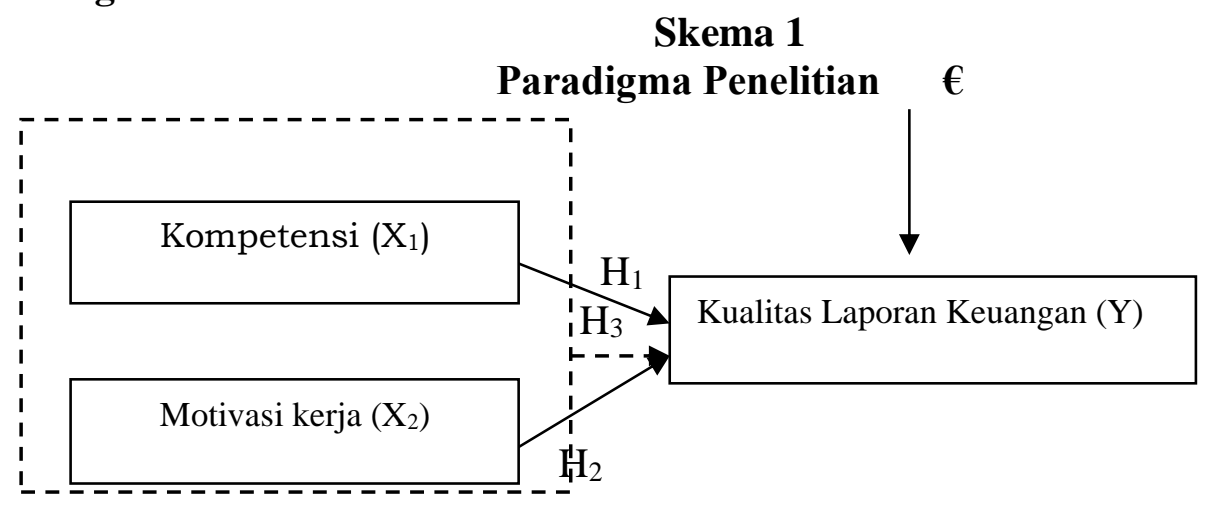

\section{Hipotesis penelitian}

$\mathrm{H}_{1}$ : Kompetensi berpengaruh positif dan signifikan terhadap kualitas laporan keuangan $\mathrm{H}_{2}$ : Motivasi kerja berpengaruh positif dan signifikan terhadap kualitas laporan keuangan $\mathrm{H}_{3}$ : Kompetensi dan motivasi kerja berpengaruh positif dan signifikan terhadap kualitas laporan keuangan

\section{METODE PENELITIAN}

Objek dalam penelitian ini adalah kompetensi dan motivasi kerja terhadap kualitas laporan keuangan instansi Pemerintah pada Kantor Badan Keuangan dan Aset Daerah (BKAD) Kabupaten Muna yang beralamat di Jalan Gatot Subroto, Sidodadi, Raha.

Populasi dalam penelitian ini adalah keseluruhan Pegawai Negeri Sipil pada Badan Keuangan dan Aset Daerah Kabupaten Muna dari jabatan yang tertinggi sampai terendah yang berjumlah 56 orang. Tekhnik sampel yang digunakan dalam penelitian ini adalah metode purposive sampling, yaitu dilakukan dengan mengambil sampel dari populasi berdasarkan suatu kriteria tertentu. Adapun kriteria pemilihan sampel yaitu :

- Responden adalah pegawai tetap yang bekerja pada bagian pengelola keuangan Badan Keuangan dan Aset Daerah Kabupaten Muna.

- Telah bekerja lebih dari satu tahun

Adapun sampel yang di ambil dari Badan Keuangan dan Aset Daerah Kabupaten Muna yaitu sebagai berikut: 
Tabel 2. Penarikan Sampel

Badan Keuangan dan Aset Daerah Kabupaten Muna

\begin{tabular}{|l|l|l|}
\hline NO. & \multicolumn{1}{|c|}{ Sub Unit } & \multicolumn{1}{c|}{ Jumlah } \\
\hline 1 & Kepala Badan & 1 Orang \\
\hline 2 & Sekretaris & 1 Orang \\
\hline 3 & Sub Bidang Akuntansi & 6 Orang \\
\hline 4 & Sub Bidang Pertanggungjawaban & 6 Orang \\
\hline 5 & Sub Bidang Perbendaharaan & 6 Orang \\
\hline Jumlah & 20 Orang \\
\hline
\end{tabular}

Sumber : Data Primer yang diolah 2019

Sumber data primer yang digunakan dalam penelitian ini adalah data yang bersumber dari pegawai pada BKAD Kabupaten Muna yang dikumpulkan melalui kuesioner. Sedangkan data sekunder dalam penelitian ini adalah data yang sumbernya diperoleh langsung dari BKAD Kabupaten Muna berupa : profil organisasi, visi-misi organisasi, dan data pegawai.

Metode pengumpulan data dalam penelitian ini adalah studi kepustakaan yaitu mengumpulkan data dan informasi yang dibutuhkan dan diperoleh dari berbagai referensi literatur, jurnal-jurnal media cetak, dokumen arsip, dan bacaan lainnya yang berkaitan dengan masalah dalam penelitian yang dapat digunakan sebagai landasan teori dan alat untuk melakukan analisis.

Metode Analisis data dalam penelitian ini menggunakan teknik analisis regresi berganda untuk mengolah dan membahas data yang telah diperoleh dan untuk menguji hipotesis yang diajukan. Seluruh rangkaian analisis data dalam penelitian ini menggunakan perangkat lunak SPSS.

Penelitian ini menggunakan dua variabel bebas sehingga persamaanya adalah sebagai berikut:

$\mathrm{Y}=\mathrm{a}+\beta 1 \mathrm{X} 1+\beta 2 \mathrm{X} 2+\varepsilon$

Dimana :

$\mathrm{Y} \quad=\quad$ Kualitas Laporan Keuangan

$\mathrm{a} \quad=\quad$ Konstanta

$\beta=$ Koefisien regresi (nilai peningkatan ataupun penurunan)

$\mathrm{X} 1=$ Kompetensi

$\mathrm{X} 2=$ Motivasi kerja

$\varepsilon=$ Standart Eror

\section{HASIL DAN PEMBAHASAN}

\section{Analisis Deskriptif Variabel Penelitian}

Penelitian ini menggunakan 3 (tiga) variabel yang terdiri dari kompetensi, motivasi kerja, serta kualitas laporan keuangan. Deskriptif penelitian bertujuan untuk menginterpretasikan mengenai distribusi frekuensi jawaban responden dari data yang telah dikumpulkan. Dalam penelitian ini jawaban responden dikategorikan dalam lima kategori dengan menggunakan skala likert. Masing-masing skala mempunyai penilaian dari sangat negatif sampai sangat positif yang dituangkan dalam pilihan jawaban kuesioner. Variabel penelitian ini mengadopsi prinsip dari pembobotan yang dikemukakan oleh solimun et al (2017). 
Jurnal Akuntansi dan Keuangan (JAK)

Volume 6, No. 1 Februari Tahun 2021

Page: 292 - 306

http://ojs.uho.ac.id/index.php/jak-uho/issue/archive

e-ISSN: 2088-4656

Tabel 3. Penentuan Kategori Rata-rata Skor pernyataan Responden

\begin{tabular}{|l|l|l|}
\hline No & Nilai Rata-Rata Skor Jawaban & Makna Kategori/Interpretasi \\
\hline 1 & $1,0<-\leq 1,80$ & Sangat Rendah/Tidak Baik \\
\hline 2 & $1,81<-\leq 2,60$ & Rendah/Kurang Baik \\
\hline 3 & $2,61<-\leq 3,40$ & Cukup Baik/Cukup Baik \\
\hline 4 & $3,41<-\leq 4,20$ & Tinggi/Baik \\
\hline 5 & $4,21<-\leq 5,0$ & Sangat Tinggi/Sangat Baik \\
\hline
\end{tabular}

Sumber : Solimun et al tahun 2017

Tabel 4. Distribusi frekuensi jawaban responden atas pernyataan variabel kompetensi $\left(\mathbf{X}_{1}\right)$

\begin{tabular}{|c|c|c|c|c|c|c|c|c|c|c|c|c|c|}
\hline \multirow{3}{*}{$\begin{array}{l}\text { Item } \\
\text { (Butir) }\end{array}$} & \multicolumn{10}{|c|}{ Frekwensi Jawaban Responden (f) \& Persentase (\%) } & \multirow{3}{*}{$\begin{array}{l}\text { Total } \\
\text { Skor }\end{array}$} & \multirow{3}{*}{$\begin{array}{l}\text { Rata- } \\
\text { Rata } \\
\text { Skor }\end{array}$} & \multirow{3}{*}{$\begin{array}{l}\text { Persentase } \\
\text { Rata-Rata } \\
\text { Skor }\end{array}$} \\
\hline & \multicolumn{2}{|c|}{ STS (1) } & \multicolumn{2}{|c|}{ TS (2) } & \multicolumn{2}{|c|}{$\mathrm{N}(3)$} & \multicolumn{2}{|c|}{$\mathrm{S}(4)$} & \multicolumn{2}{|c|}{ SS (5) } & & & \\
\hline & $\mathrm{F}$ & $\%$ & $\mathrm{~F}$ & $\%$ & $\mathrm{~F}$ & $\%$ & $\mathrm{~F}$ & $\%$ & $\mathrm{f}$ & $\%$ & & & \\
\hline $\mathrm{X} 1.1 .1$ & 0 & 0 & 0 & 0 & 0 & 0 & 13 & 65 & 7 & 35 & 87 & 4,35 & 87,00 \\
\hline $\mathrm{X} 1.1 .2$ & 0 & 0 & 0 & $\overline{0}$ & 0 & 0 & 12 & 60 & 8 & 40 & 88 & 4,40 & 88,00 \\
\hline $\mathrm{X} 1.1 .3$ & 0 & 0 & 0 & $\overline{0}$ & 3 & 15 & 10 & 50 & 7 & 35 & 84 & 4,20 & 84,00 \\
\hline $\mathrm{X} 1.1 .4$ & 0 & 0 & 0 & 0 & 3 & 15 & 10 & 50 & 7 & 35 & 84 & 4,20 & 84,00 \\
\hline $\mathrm{X} 1.1 .5$ & 0 & 0 & 0 & 0 & 0 & 0 & 13 & 65 & 7 & 35 & 87 & 4,35 & 87,00 \\
\hline \multicolumn{11}{|c|}{ Rata-rata indikator Pengetahuan X1.1) } & 430 & 4,30 & 86,00 \\
\hline $\mathrm{X} 1.2 .1$ & 0 & 0 & 0 & 0 & 0 & 0 & 14 & 70 & 6 & 30 & 86 & 4,30 & 86,00 \\
\hline $\mathrm{X} 1.2 .2$ & 0 & 0 & 0 & 0 & 0 & 0 & 12 & 60 & 8 & 40 & 88 & 4,40 & 88,00 \\
\hline $\mathrm{X} 1.2 .3$ & 0 & 0 & 0 & 0 & 0 & 0 & 16 & 80 & 4 & 20 & 84 & 4,20 & 86,00 \\
\hline $\mathrm{X} 1.2 .4$ & 0 & 0 & 0 & 0 & 0 & 0 & 14 & 70 & 6 & 30 & 86 & 4,30 & 86,00 \\
\hline \multicolumn{11}{|c|}{ Rata-rata indikator Keterampilan (X1.2) } & 344 & 4,30 & 86,00 \\
\hline $\mathrm{X} 1.3 .1$ & 0 & 0 & 0 & 0 & 3 & 15 & 15 & 75 & 2 & 10 & 79 & 3,95 & 79,00 \\
\hline $\mathrm{X} 1.3 .2$ & 0 & 0 & 0 & 0 & 1 & 5 & 14 & 70 & 5 & 25 & 84 & 4,20 & 84,00 \\
\hline $\mathrm{X} 1.3 .3$ & 0 & 0 & 0 & 0 & 0 & 0 & 18 & 90 & 2 & 10 & 82 & 4,10 & 82,00 \\
\hline $\mathrm{X} 1.3 .4$ & 0 & 0 & 0 & $\overline{0}$ & 3 & 15 & 16 & 80 & 1 & 5 & 78 & 3,90 & 78,00 \\
\hline $\mathrm{X} 1.3 .5$ & 0 & 0 & 0 & 0 & 0 & 0 & 17 & 85 & 3 & 15 & 83 & 4,15 & 83,00 \\
\hline $\mathrm{X} 1.3 .6$ & 0 & 0 & 0 & 0 & 4 & 20 & 12 & 60 & 4 & 20 & 80 & 4,00 & 80,00 \\
\hline \multirow{2}{*}{\multicolumn{11}{|c|}{ Rata-rata Indikator Sikap }} & 486 & 4,05 & 81,00 \\
\hline & & & & & & & & & & & 1260 & 4,20 & 84,00 \\
\hline
\end{tabular}

Berdasarkan distribusi skor jawaban responden atas variabel kompetensi $\left(\mathrm{X}^{1}\right)$ pada tabel 4 dapat diketahui bahwa dari 20 responden yang diteliti, secara umum persepsi responden terhadap item-item pernyataan kompetensi berada pada rata-rata skor 4,20 dengan kategori baik.

Tabel 5. Distribusi Frekuensi Jawaban Responden Atas Pernyataan Variabel Motivasi Kerja $\left(\mathbf{X}_{2}\right)$

\begin{tabular}{|c|c|c|c|c|c|c|c|c|c|c|c|c|c|}
\hline \multirow{3}{*}{$\begin{array}{l}\text { Item } \\
\text { (Butir) }\end{array}$} & \multicolumn{10}{|c|}{ Frekwensi Jawaban Responden (f) \& Persentase (\%) } & \multirow{3}{*}{$\begin{array}{l}\text { Total } \\
\text { Skor }\end{array}$} & \multirow{3}{*}{$\begin{array}{l}\text { Rata- } \\
\text { Rata } \\
\text { Skor }\end{array}$} & \multirow{3}{*}{$\begin{array}{l}\text { Persentase } \\
\text { Rata-Rata } \\
\text { Skor }\end{array}$} \\
\hline & \multicolumn{2}{|c|}{ STS (1) } & \multicolumn{2}{|c|}{ TS (2) } & \multicolumn{2}{|c|}{$\mathrm{N}(3)$} & \multicolumn{2}{|c|}{ S (4) } & \multicolumn{2}{|c|}{ SS (5) } & & & \\
\hline & $\bar{F}$ & $\%$ & $\bar{F}$ & $\%$ & $\bar{F}$ & $\%$ & $\bar{F}$ & $\%$ & $\bar{F}$ & $\%$ & & & \\
\hline $\mathrm{X} 2.1 .1$ & 0 & 0 & 0 & 0 & 0 & 0 & 13 & 65 & 7 & 35 & 87 & 4,35 & 87,00 \\
\hline $\mathrm{X} 2.1 .2$ & 0 & 0 & 0 & 0 & 1 & 5 & 15 & 75 & 4 & 20 & 83 & 4,15 & 83,00 \\
\hline $\mathrm{X} 2.1 .3$ & 0 & 0 & 0 & 0 & 2 & 10 & 14 & 70 & 4 & 20 & 82 & 4,10 & 82,00 \\
\hline \multicolumn{11}{|c|}{ Rata-rata indikator Kebutuhan (X2.1) } & 252 & 4,20 & 84,00 \\
\hline $\mathrm{X} 2.2 .1$ & 0 & 0 & 0 & 0 & 1 & 5 & 16 & 80 & 3 & 15 & 82 & 4,10 & 82,00 \\
\hline $\mathrm{X} 2.2 .2$ & 0 & 0 & 0 & 0 & 3 & 15 & 15 & 75 & 2 & 10 & 79 & 3,95 & 79,00 \\
\hline \multicolumn{11}{|c|}{ Rata-rata indikator Dorongan (X2.2) } & 161 & 4,03 & 80,50 \\
\hline $\mathrm{X} 2.3 .1$ & 0 & 0 & 0 & 0 & 4 & 20 & 12 & 60 & 4 & 20 & 80 & 4,00 & 80,00 \\
\hline $\mathrm{X} 2.3 .2$ & 0 & 0 & 1 & 5 & 3 & 15 & 13 & 65 & 3 & 15 & 78 & 3,90 & 78,00 \\
\hline \multicolumn{11}{|c|}{ Rata-rata indikator Tujuan (X2.3) } & 158 & 3,95 & 79,00 \\
\hline \multicolumn{11}{|c|}{ Rata-rata Variabel Motivasi Kerja (X2) } & 571 & 4,08 & 81,57 \\
\hline
\end{tabular}


Jurnal Akuntansi dan Keuangan (JAK)

Volume 6, No. 1 Februari Tahun 2021

Page: 292 - 306

http://ojs.uho.ac.id/index.php/jak-uho/issue/archive

e-ISSN: 2088-4656

Berdasarkan distribusi skor jawaban responden atas variabel motivasi kerja $\left(\mathrm{X}^{2}\right)$ pada tabel 5 dapat diketahui bahwa dari 20 responden yang diteliti, secara umum persepsi responden terhadap item-item pernyataan motivasi kerja berada pada rata-rata skor 4,08 dengan kategori baik.

Tabel 6. Distribusi Frekuensi Jawaban Responden Atas Pernyataan Variabel Kualitas Laporan Keuangan (Y)

\begin{tabular}{|c|c|c|c|c|c|c|c|c|c|c|c|c|c|}
\hline \multirow{3}{*}{$\begin{array}{l}\text { Item } \\
\text { (Butir) }\end{array}$} & \multicolumn{10}{|c|}{ Frekwensi Jawaban Responden (f) \& Persentase (\%) } & \multirow{3}{*}{$\begin{array}{l}\text { Total } \\
\text { Skor }\end{array}$} & \multirow{3}{*}{$\begin{array}{l}\text { Rata- } \\
\text { Rata } \\
\text { Skor }\end{array}$} & \multirow{3}{*}{$\begin{array}{l}\text { Persentase } \\
\text { Rata-Rata } \\
\text { Skor }\end{array}$} \\
\hline & \multicolumn{2}{|c|}{ STS (1) } & \multicolumn{2}{|c|}{ TS (2) } & \multicolumn{2}{|c|}{$\mathrm{N}(3)$} & \multicolumn{2}{|c|}{ S (4) } & \multicolumn{2}{|c|}{ SS (5) } & & & \\
\hline & $\mathrm{F}$ & $\%$ & $\mathrm{~F}$ & $\%$ & $\mathrm{~F}$ & $\%$ & $f$ & $\%$ & $\mathrm{~F}$ & $\%$ & & & \\
\hline $\mathrm{Y} 1.1 .1$ & 0 & 0 & 0 & 0 & 0 & 0 & 13 & 65 & 7 & 35 & 87 & 4,35 & 87,00 \\
\hline $\mathrm{Y} 1.1 .2$ & 0 & 0 & 0 & 0 & 0 & 0 & 12 & 60 & 8 & 40 & 88 & 4,40 & 88,00 \\
\hline Y1.1.3 & 0 & 0 & 0 & 0 & 0 & 0 & 13 & 65 & 7 & 35 & 87 & 4,35 & 87,00 \\
\hline \multicolumn{11}{|c|}{ Rata-rata inikator Relevan (Y1.1) } & 262 & 4,37 & 87,33 \\
\hline Y1.2.1 & 0 & 0 & 0 & 0 & 0 & 0 & 11 & 55 & 9 & 45 & 89 & 4,45 & 89,00 \\
\hline $\mathrm{Y} 1.2 .2$ & 0 & 0 & 0 & 0 & 0 & 0 & 17 & 85 & 3 & 15 & 83 & 4,15 & 83,00 \\
\hline $\mathrm{Y} 1.2 .3$ & 0 & 0 & 0 & 0 & 0 & 0 & 15 & 75 & 5 & 25 & 85 & 4,25 & 85,00 \\
\hline Y1.2.4 & 0 & 0 & 0 & 0 & 1 & 5 & 11 & 55 & 8 & 40 & 87 & 4,35 & 87,00 \\
\hline \multicolumn{11}{|c|}{ Rata-rata indikator Andal (Y1.2) } & 344 & 4,30 & 86,00 \\
\hline Y1.3.1 & 0 & 0 & 0 & 0 & 0 & 0 & 13 & 65 & 7 & 35 & 87 & 4,35 & 87,00 \\
\hline Y1.3.2 & 0 & 0 & 0 & 0 & 0 & 0 & 15 & 75 & 5 & 25 & 85 & 4,25 & 85,00 \\
\hline \multicolumn{11}{|c|}{ Rata-rata indikator Dapat Dibandingkan (Y1.3) } & 172 & 4,30 & 86,00 \\
\hline Y1.4.1 & 0 & 0 & 0 & 0 & 0 & 0 & 14 & 70 & 6 & 30 & 86 & 4,30 & 86,00 \\
\hline Y1.4.2 & 0 & 0 & 0 & 0 & 0 & 0 & 15 & 75 & 5 & 25 & 85 & 4,25 & 85,00 \\
\hline \multicolumn{11}{|c|}{ Rata-rata indikator Dapat Dipahami (Y2.4) } & 171 & 4,28 & 85,50 \\
\hline \multicolumn{11}{|c|}{ Rata-rata variabel Kualitas Laporan Keuangan (Y1) } & 949 & 4,31 & 86,27 \\
\hline
\end{tabular}

Berdasarkan distribusi skor jawaban responden atas variabel kualitas laporan keuangan (Y) pada tabel 6 dapat diketahui bahwa dari 20 responden yang diteliti, secara umum persepsi responden terhadap item-item pernyataan kualitas laporan keuangan berada pada rata-rata skor 4,31 dengan kategori sangat baik.

\section{Uji kualitas data (Uji validitas dan reliabilitas)}

Hasil koefisien korelasi dan cronbach alpha untuk menguji validitas dan reliabilitas penggunaan item pernyataan dari indikator-indikator variabel kompetensi adalah sebagai berikut:

Tabel 7. Hasil Uji Validitas dan Reliabilitas Variabel Kompetensi

\begin{tabular}{|c|c|c|c|c|c|c|}
\hline $\begin{array}{l}\text { Indikator } \\
\text { Variabel }\end{array}$ & $\begin{array}{l}\text { Item } \\
\text { Pernyataan }\end{array}$ & $\begin{array}{l}\text { Koefisien } \\
\text { Korelasi }\end{array}$ & Sig & Ket & $\begin{array}{l}\text { Cronbach } \\
\text { Alpha }\end{array}$ & Ket \\
\hline $\begin{array}{l}\text { Pengetahuan } \\
\left(\mathrm{X}_{1.1}\right)\end{array}$ & $\begin{array}{l}\mathrm{X} 1.1 .1 \\
\mathrm{X} 1.1 .2 \\
\mathrm{X} 1.1 .3 \\
\mathrm{X} 1.1 .4 \\
\mathrm{X} 1.1 .5 \\
\end{array}$ & $\begin{array}{l}0,686 \\
0.792 \\
0,715 \\
0,679 \\
0,839 \\
\end{array}$ & $\begin{array}{l}0 \\
0 \\
0 \\
0 \\
0\end{array}$ & $\begin{array}{l}\text { Valid } \\
\text { Valid } \\
\text { Valid } \\
\text { Valid } \\
\text { Valid } \\
\end{array}$ & 0,775 & Reliabel \\
\hline $\begin{array}{l}\text { Keterampilan } \\
\left(\mathrm{X}_{1.2}\right)\end{array}$ & $\begin{array}{l}\mathrm{X} 1.2 .1 \\
\mathrm{X} 1.2 .2 \\
\mathrm{X} 1.2 .3 \\
\mathrm{X} 1.2 .4\end{array}$ & $\begin{array}{l}0,661 \\
0,824 \\
0,699 \\
0,661 \\
\end{array}$ & $\begin{array}{l}0 \\
0 \\
0 \\
0\end{array}$ & $\begin{array}{l}\text { Valid } \\
\text { Valid } \\
\text { Valid } \\
\text { Valid } \\
\end{array}$ & 0,675 & Reliabel \\
\hline Sikap $\left(\mathrm{X}_{1.3}\right)$ & $\begin{array}{l}X 1.3 .1 \\
X 1.3 .2 \\
X 1.3 .3 \\
X 1.3 .4 \\
X 1.3 .5 \\
X 1.3 .6\end{array}$ & $\begin{array}{l}0,779 \\
0,634 \\
0,622 \\
0,847 \\
0,642 \\
0,761 \\
\end{array}$ & $\begin{array}{l}0 \\
0 \\
0 \\
0 \\
0 \\
0\end{array}$ & $\begin{array}{l}\text { Valid } \\
\text { Valid } \\
\text { Valid } \\
\text { Valid } \\
\text { Valid } \\
\text { Valid }\end{array}$ & 0,796 & Reliabel \\
\hline
\end{tabular}


Tabel 7 terlihat bahwa semua indikator pada variabel Kompetensi menunjukkan hasil yang valid dan reliabel. Keputusan ini diambil karena nilai koefisien korelasi $r \geq 0,30$ dan cronbach alpha $(\alpha) \geq 0,60$, dengan tingkat sangat signifikan $(0,000)$. Indikator yang sangat kuat mencerminkan kompetensi secara berurutan adalah aktivitas sikap $\left(\mathrm{X}_{1.3}\right)$ dengan nilai cronbach alpha adalah 0,796 , pengetahuan $\left(\mathrm{X}_{1.1}\right)$ dengan nilai cronbach alpha adalah 0,775 , keterampilan $\left(\mathrm{X}_{1.2}\right)$ dengan nilai cronbach alpha adalah 0,675 .

Hasil koefisien korelasi dan cronbach alpha untuk menguji validitas dan reliabilitas penggunaan item pernyataan dari indikator-indikator variabel motivasi kerja adalah sebagai berikut:

Tabel 8. Hasil Uji Validitas dan Reliabilitas Variabel Motivasi kerja

\begin{tabular}{|c|c|c|c|c|c|c|}
\hline $\begin{array}{l}\text { Indikator } \\
\text { Variabel }\end{array}$ & $\begin{array}{l}\text { Item } \\
\text { Pernyataan }\end{array}$ & $\begin{array}{l}\text { Koefisien } \\
\text { Korelasi }\end{array}$ & Sig & Ket & $\begin{array}{l}\text { Cronbach } \\
\text { Alpha }\end{array}$ & Ket \\
\hline $\begin{array}{l}\text { Kebutuhan } \\
\left(\mathrm{X}_{2.1}\right)\end{array}$ & $\begin{array}{l}\mathrm{X} 2.1 .1 \\
\mathrm{X} 2.1 .2 \\
\mathrm{X} 2.1 .3\end{array}$ & $\begin{array}{l}0,797 \\
0,743 \\
0,785\end{array}$ & $\begin{array}{l}0 \\
0 \\
0\end{array}$ & $\begin{array}{l}\text { Valid } \\
\text { Valid } \\
\text { Valid }\end{array}$ & 0,666 & Reliabel \\
\hline $\begin{array}{l}\text { Dorongan } \\
\left(\mathrm{X}_{2.2}\right)\end{array}$ & $\begin{array}{l}\mathrm{X} 2.2 .1 \\
\mathrm{X} 2.2 .2 \\
\end{array}$ & $\begin{array}{l}0,841 \\
0,881\end{array}$ & $\begin{array}{l}0 \\
0 \\
\end{array}$ & $\begin{array}{l}\text { Valid } \\
\text { Valid }\end{array}$ & 0,649 & Reliabel \\
\hline Tujuan $\left(\mathrm{X}_{2.3}\right)$ & $\begin{array}{l}\mathrm{X} 2.3 .1 \\
\mathrm{X} 2.3 .2\end{array}$ & $\begin{array}{l}0,835 \\
0,868\end{array}$ & $\begin{array}{l}0 \\
0\end{array}$ & $\begin{array}{l}\text { Valid } \\
\text { Valid }\end{array}$ & 0,620 & Reliabel \\
\hline
\end{tabular}

Tabel 8 terlihat bahwa semua indikator pada variabel motivasi kerja menunjukkan hasil yang valid dan reliabel. Keputusan ini diambil karena nilai koefisien korelasi $r \geq 0,30$ dan cronbach alpha $(\alpha) \geq 0,60$, dengan tingkat sangat signifikan $(0,000)$. Indikator yang sangat kuat mencerminkan motivasi kerja secara berurutan adalah kebutuhan $\left(\mathrm{X}_{2.1}\right)$ dengan nilai cronbach alpha adalah 0,666 , dorongan $\left(\mathrm{X}_{2.2}\right)$ dengan nilai cronbach alpha adalah 0,649 , tujuan $\left(\mathrm{X}_{2.3}\right)$ dengan nilai cronbach alpha adalah 0,620.

Hasil koefisien korelasi dan cronbach alpha untuk menguji validitas dan reliabilitas penggunaan item pernyataan dari indikator-indikator variabel kualitas laporan keuangan adalah sebagai berikut:

Tabel 9. Hasil Uji Validitas dan Reliabilitas Variabel Kualitas Laporan Keuangan

\begin{tabular}{|c|c|c|c|c|c|c|}
\hline $\begin{array}{l}\text { Indikator } \\
\text { Variabel }\end{array}$ & $\begin{array}{l}\text { Item } \\
\text { Pernyataan }\end{array}$ & $\begin{array}{l}\text { Koefisien } \\
\text { Korelasi }\end{array}$ & Sig & Ket & $\begin{array}{l}\text { Cronbach } \\
\text { Alpha }\end{array}$ & Ket \\
\hline Relevan $\left(\mathrm{Y}_{1.1}\right)$ & $\begin{array}{l}\text { Y1.1.1 } \\
\text { Y1.1.2 } \\
\text { Y1.1.3 }\end{array}$ & $\begin{array}{l}0,798 \\
0,862 \\
0,603\end{array}$ & $\begin{array}{l}0 \\
0 \\
0\end{array}$ & $\begin{array}{l}\text { Valid } \\
\text { Valid } \\
\text { Valid }\end{array}$ & 0,624 & Reliabel \\
\hline Andal $\left(\mathrm{Y}_{1.2}\right)$ & $\begin{array}{l}\text { Y1.2.1 } \\
\text { Y1.2.2 } \\
\text { Y1.2.3 } \\
\text { Y1.2.4 }\end{array}$ & $\begin{array}{l}0,854 \\
0,722 \\
0,563 \\
0,889\end{array}$ & $\begin{array}{l}0 \\
0 \\
0 \\
0\end{array}$ & $\begin{array}{l}\text { Valid } \\
\text { Valid } \\
\text { Valid } \\
\text { Valid } \\
\end{array}$ & 0,757 & Reliabel \\
\hline $\begin{array}{l}\text { Dapat } \\
\text { dibandingkan } \\
\left(\mathrm{Y}_{1.3}\right)\end{array}$ & $\begin{array}{l}\text { Y1.3.1 } \\
\text { Y1.3.2 }\end{array}$ & $\begin{array}{l}0,891 \\
0,866 \\
\end{array}$ & $\begin{array}{l}0 \\
0 \\
\end{array}$ & $\begin{array}{l}\text { Valid } \\
\text { Valid }\end{array}$ & 0,703 & Reliabel \\
\hline $\begin{array}{l}\text { Dapat dipahami } \\
\left(\mathrm{Y}_{1.4}\right)\end{array}$ & $\begin{array}{l}\text { Y1.4.1 } \\
\text { Y1.4.2 }\end{array}$ & $\begin{array}{l}0,908 \\
0,897 \\
\end{array}$ & $\begin{array}{l}0 \\
0 \\
\end{array}$ & $\begin{array}{l}\text { Valid } \\
\text { Valid } \\
\end{array}$ & 0,772 & Reliable \\
\hline
\end{tabular}

Tabel 9 terlihat bahwa semua indikator pada variabel motivasi kerja menunjukkan hasil yang valid dan reliabel. Keputusan ini diambil karena nilai koefisien korelasi $r \geq 0,30$ dan cronbach alpha $(\alpha) \geq 0,60$, dengan tingkat sangat signifikan $(0,000)$. Indikator yang sangat kuat adalah dapat dipahami $\left(\mathrm{Y}_{1.4}\right)$ dengan nilai cronbach alpha adalah 0,772 , andal ( $\mathrm{Y}_{1.2}$ ) dengan nilai cronbach alpha adalah 0,757, dapat dibandingkan $\left(\mathrm{Y}_{1.3}\right)$ dengan nilai cronbach alpha adalah 0,703 , relevan $\left(\mathrm{Y}_{1.1}\right)$, dengan nilai cronbach alpha adalah 0,624. 
Jurnal Akuntansi dan Keuangan (JAK)

Volume 6, No. 1 Februari Tahun 2021

Page: 292 - 306

http://ojs.uho.ac.id/index.php/jak-uho/issue/archive

e-ISSN: 2088-4656

\section{Uji asumsi klasik}

a. Uji normalitas

Uji normalitas perlu dilakukan untuk menguji apakah dalam sebuah model regresi, variabel dependen, variabel independen atau keduanya mempunyai distribusi normal ataukah tidak. Syarat untuk mendapatkan model regresi yang baik adalah distribusi datanya normal atau mendekati normal. Untuk menguji normalitas ini dapat diketahui dari tampilan grafik Normal Probability Plot (P-P Plot Test) dan grafik histogram.

\section{Gambar 1}

\section{Normal probability plot}

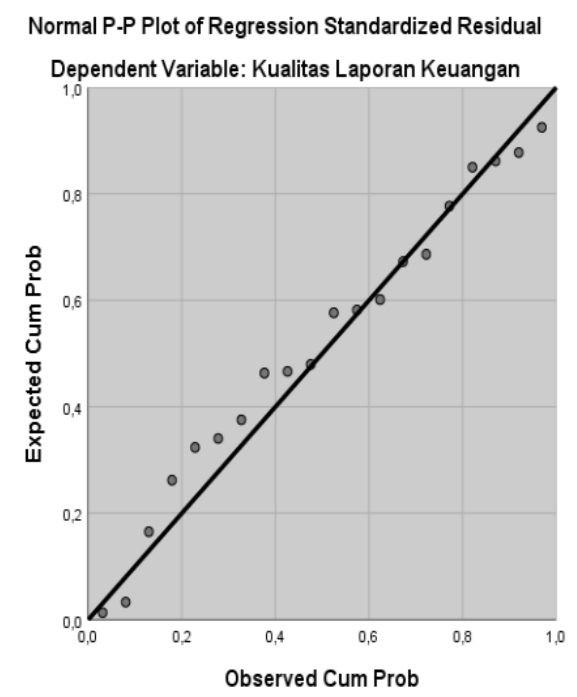

Sumber : Data Primer Diolah, Tahun 2019 dengan Program SPSS Versi 26

Uji normalitas data dilakukan dengan menggunakan histogram standardized residual dan p-p plot standardized residual. grafik probability plot menunjukan bahwa titiktitik menyebar disekitar garis diagonal dan penyebarannya mengikuti arah garis diagonal. Jadi model regresi ini layak dipakai dalam penelitian ini karena memenuhi asumsi normalitas.

b. Uji multikolinearitas

Tabel 10

Hasil uji multikolinearitas

\begin{tabular}{|ll|l|l|}
\hline \multirow{2}{*}{ Model } & \multicolumn{3}{|l|}{ Collinearity Statistics } \\
\cline { 2 - 4 } & Tolerance & VIF \\
\hline 1 & (Constant) & & \\
& Kompetensi & 1,000 & 1,000 \\
& Motivasi Kerja & 1,000 & 1,000 \\
\hline
\end{tabular}

Untuk mendeteksi adanya multikolinearitas dengan melihat nilai dari VIF kurang dari 10 dan nilai tolerance lebih dari 0,1 atau $10 \%$ yang mengindikasikan tidak adanya multikolinearitas. Nilai VIF dari masing-masing variabel independen kurang dari 10 dan nilai tolerance lebih dari 0,1 dapat disimpulkan bahwa model regresi ini terbebas dari multikolinearitas.

c. Uji Autokorelasi

Uji autokorelasi dalam penelitian ini dilakukan dengan menggunakan uji Durbin Watson. Nilai Durbin Watson yang berada antara nilai du 4 - du menunjukkan nilai yang tidak terkena masalah autokorelasi. Adapun untuk melihat autokorelasi dalam penelitian ini, yaitu : 
a. Angka D-W dibawah -4 berarti ada autokorelasi positif

b. Angka D-W antara -4 sampai +4 , berarti tidak ada autokorelasi

c. Angka D-W dibawah +4 berarti ada autokorelasi negatif.

Berdasarkan hasil uji autokorelasi untuk nilai dari Durbin-Watson yaitu 3,068 dimana nilai tersebut dinyatakan bebas dari autokorelasi, karena berada diantara nilai -4 dan diatas +4 . Jadi model regresi dalam penelitian ini bebas dari autokorelasi.

d. Uji heterokedastisitas

Gambar 2

Scatterplot

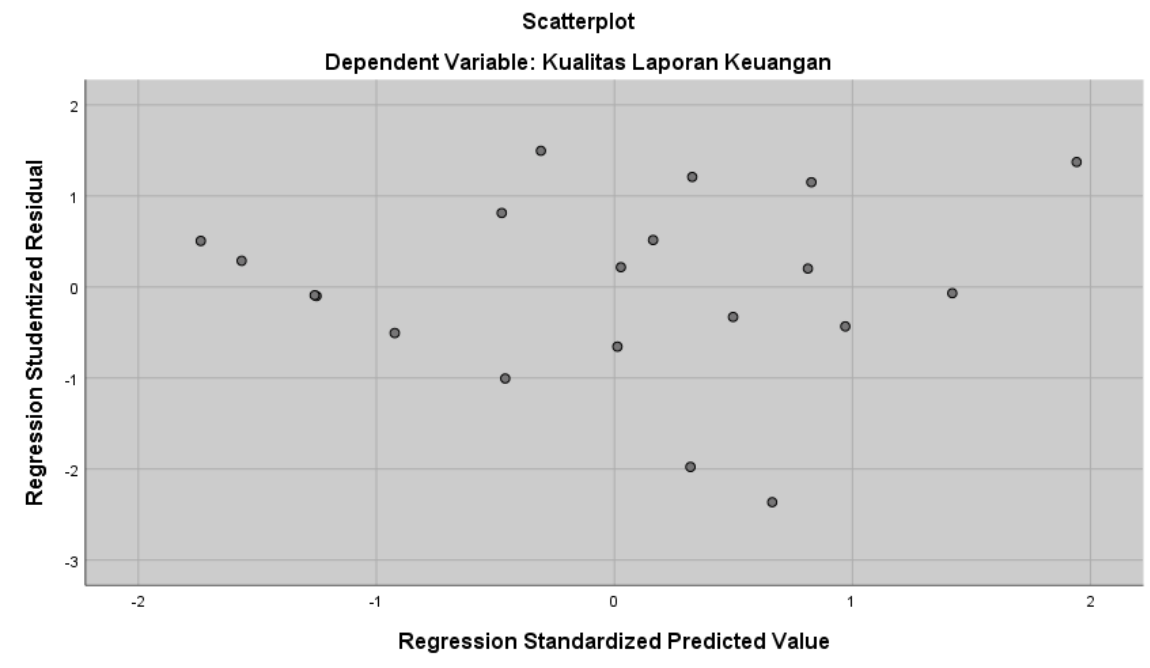

Sumber : Data Primer Diolah, Tahun 2019 dengan Program SPSS Versi 26

Dari gambar scatterplot terlihat data menyebar secara acak, tidak membentuk sebuah pola tertentu yang jelas, serta tersebar baik diatas maupun dibawah angka 0 pada sumbu Y. jadi dapat disimpulkan bahwa model regresi tidak terjadi heterokedastisitas.

Analisis regresi berganda

Tabel 11

Hasil uji regresi linear berganda

\begin{tabular}{|l|l|l|l|l|l|l|}
\hline \multirow{2}{*}{ Model } & \multicolumn{2}{|l|}{$\begin{array}{l}\text { Unstandardized } \\
\text { Coefficients }\end{array}$} & $\begin{array}{l}\text { Standardized } \\
\text { Coefficients }\end{array}$ & & \\
\cline { 3 - 7 } & B & $\begin{array}{l}\text { Std. } \\
\text { Error }\end{array}$ & Beta & T & Sig. \\
\hline \multirow{3}{*}{1} & (Constant) & 45,592 & 10,012 & & 4,554 &, 000 \\
\cline { 2 - 7 } & Kompetensi &, 406 &, 119 &, 535 & 3,402 &, 003 \\
\cline { 2 - 7 } & Motivasi Kerja &, 831 &, 236 &, 553 & 3,517 &, 003 \\
\hline
\end{tabular}

Sumber : Data Primer Diolah, Tahun 2019 dengan Program SPSS Versi 26

Analisis regresi berganda dilakukan untuk mengetahui hubungan fungsional antar beberapa variabel bebas (independen) secara bersama-sama terhadap variabel terikat (dependen). Penelitian membuktikan mengenai besarnya seluruh variabel bebas yaitu kompetensi, motivasi kerja, terhadap variabel terikat yaitu kualitas laporan keuangan.

\section{Uji hipotesis}

a. Pengaruh kompetensi terhadap kualitas laporan keuangan

Berdasarkan tabel 3 terlihat koefisien regresi pengaruh langsung kompetensi dengan nilai $\beta=0,535$ dengan tingkat signifikan $0,003<0,05$ dan nilai $t_{\text {hitung }}=3,402>t_{\text {abel }}=2,110$. Maka hipotesis yang menyataan bahwa kompetensi berpengaruh positif dan signifikan 
Jurnal Akuntansi dan Keuangan (JAK)

Volume 6, No. 1 Februari Tahun 2021

Page: 292 - 306

http://ojs.uho.ac.id/index.php/jak-uho/issue/archive

e-ISSN: 2088-4656

terhadap kualitas laporan keuangan, hal ini dibuktikan dengan nilai signifikansi lebih kecil dari 0,05 .

b. Pengaruh motivasi kerja terhadap kualitas laporan keuangan

Pengujian hipotesis dengan pendekatan analisis regresi, berdasarkan tabel diatas menghasilkan koefisien regresi pengaruh langsung motivasi kerja terhadap kualitas laporan keuangan dengan nilai $\beta=0,553$ dengan tingkat signifikan $0,003<0,05$ dan nilai thitung $=$ $3,517>\mathrm{t}_{\text {tabel }}=2,110$. Maka hipotesis yang menyatakan bahwa motivasi kerja berpengaruh positif dan signifikan terhadap kualitas laporan keuangan dapat diterima, hal ini dibuktikan dengan nilai signifikansi lebih kecil dari 0,05.

Uji simultan

Tabel 12

Hasil uji simultan

\begin{tabular}{|l|l|l|l|l|l|l|}
\hline \multirow{3}{*}{ Model } & & $\begin{array}{l}\text { Sum of } \\
\text { Squares }\end{array}$ & Df & $\begin{array}{l}\text { Mean } \\
\text { Square }\end{array}$ & F & Sig. \\
\hline \multirow{4}{*}{1} & Regression & 126,938 & 2 & 63,469 & 11,727 &, $001^{\text {b }}$ \\
\cline { 2 - 8 } & Residual & 92,012 & 17 & 5,412 & & \\
\cline { 2 - 8 } & Total & 218,950 & 19 & & & \\
\hline
\end{tabular}

Uji F dimaksudkan untuk menguji pengaruh keseluruhan variabel bebas terhadap variabel terikat. Uji $\mathrm{F}$ dapat dilakukan dengan membandingkan nilai $\mathrm{F}_{\text {-hitung }}$ dengan $\mathrm{F}_{\text {-tabel }}$ dengan tingkat signifikansi $<$ dari $\alpha=0,05$. Apabila nilai $\mathrm{F}_{\text {-hitung }}>$ dari $\mathrm{F}_{\text {-tabel }}$ atau F-sig $<$ dari $\alpha=0,05$ maka $\mathrm{H}_{0}$ ditolak.Hasil uji diperoleh nilai $\mathrm{F}_{\text {-hitung }}$ sebesar 11,727 > dari $\mathrm{F}_{\text {-tabel }}$ dengan tingkat signifikansi F sebesar $0,001<$ dari $\alpha=0,05$, maka dapat disimpulkan bahwa $\mathrm{H}_{3}$ diterima. Hal ini berarti bahwa semua variabel bebas yakni kompetensi dan motivasi kerja secara simultan berpengaruh dan signifikan terhadap kualitas laporan keuangan. Atas dasar ini maka hipotesis penelitian yang diajukan sebelumnya dapat diterima karena terbukti kebenarannya.

Koefisien determinasi

Tabel 13

Koefisien determinasi $\left(\mathbf{R}^{\mathbf{2}}\right)$

\begin{tabular}{|l|l|l|l|l|l|}
\hline Model & $\mathrm{R}$ & R Square & $\begin{array}{l}\text { Adjusted R } \\
\text { Square }\end{array}$ & $\begin{array}{l}\text { Std. Error } \\
\text { of the } \\
\text { Estimate }\end{array}$ & $\begin{array}{l}\text { Durbin- } \\
\text { Watson }\end{array}$ \\
\hline 1 &, $761^{\mathrm{a}}$ &, 580 &, 530 & 2,32647 & 3,068 \\
\hline
\end{tabular}

Sumber : Data Primer Diolah, Tahun 2019 dengan Program SPSS Versi 26

Nilai koefisien determinasi $\left(\mathrm{R}^{2}\right)$ dalam penelitian ini adalah sebesar 0,580 yang menunjukan bahwa besarnya pengaruh kompetensi, motivasi kerja, terhadap kualitas laporan keuangan $58 \%$. Dengan demikian variabel independen yang digunakan dalam penelitian ini memiliki peranan penting terhadap kualitas laporan keuangan.

\section{a. Pengaruh Kompetensi terhadap Kualitas Laporan Keuangan}

Berdasarkan hasil pengujian hipotesis memperlihatkan variabel bahwa variabel kompetensi memiliki nilai signifikan 0,003 lebih kecil dari $\alpha=0,05$ atau $t_{\text {hitung }}>t_{\text {tabel }}(3,402$ $>2,110$ ) dan memiliki nilai koefisien 0,406, maka dapat disimpulkan bahwa variabel kompetensi berpengaruh positif dan signifikan terhadap kualitas laporan keuangan.

Hasil penelitian ini sesuai dengan penelitian yang dilakukan oleh Nurilla (2014) yang menyatakan bahwa kompetensi sumber daya manusia berpengaruh terhadap kualitas laporan keuangan pemerintah daerah. Dalam organisasi publik, peran sumber daya manusia ditekankan pada kemampuan memberikan pelayanan yang terbaik bagi masyarakat, 
sehingga organisasi tetap memiliki reputasi kinerja yang unggul dan akuntabel dimata masyarakat. Seseorang yang memiliki kompetensi akan bekerja dengan pengetahuan dan keterampilannya sehingga dapat bekerja dengan mudah, cepat, intuitif, dan dengan pengalamannya bisa meminimalisir kesalahan.

Berdasarkan jawaban responden, indikator yang paling dominan dalam kompetensi yaitu pengetahuan dan keterampilan 4,30. Hal ini dapat dilihat dari rata-rata skor tanggapan responden terhadap item ini yang berada pada kategori sangat baik. Menurut Moeheriono (2010), kompetensi pengetahuan dan keterampilan cenderung lebih mudah untuk dikembangkan dengan adanya pendidikan dan pelatihan, sedangkan kompetensi konsep diri, watak dan motif berada personality iceberg, lebih tersembunyi, sehingga cukup sulit untuk dikembangkan.

Apabila sumber daya manusia yang melaksanakan sistem akuntansi tidak memiliki keahlian dibidangnya, maka akan menimbulkan hambatan dalam proses pelaksanan fungsi akuntansi. Kegagalan yang dialami oleh sumber daya manusia dalam memahami serta menerapkan ilmu akuntansi akan memiliki dampak pada laporan keuangan, seperti adanya kekeliruan laporan yang dibuat dengan standar yang telah ditetapkan pemerintah, sehingga kualitasnya menjadi buruk. Hal ini menunjukkan bahwa kemampuan sumber daya manusia yang baik, akan meningkatkan kualitas laporan keuangan pemerintah yang dihasilkan.

\section{b. Pengaruh Motivasi Kerja terhadap Kualitas Laporan Keuangan}

Berdasarkan hasil pengujian hipotesis memperlihatkan variabel bahwa variabel motivasi kerja memiliki nilai signifikan 0,003 lebih kecil dari $\alpha=0,05$ atau $t_{\text {hitung }}>t_{\text {tabel }}$ $(3,517>2,110)$ dan memiliki nilai koefisien 0,831, maka dapat disimpulkan bahwa variabel motivasi kerja berpengaruh positif dan signifikan terhadap kualitas laporan keuangan. Hasil penelitian ini menunjukkan bahwa pegawai Badan Keuangan dan Aset Daerah Kabupaten Muna mempunyai motivasi kerja yang tinggi. Berdasarkan jawaban responden, indikator yang paling dominan dalam motivasi kerja yaitu kebutuhan 4,20. Hal ini dapat dilihat dari rata-rata skor tanggapan responden terhadap item ini yang berada pada kategori baik.

Untuk mendapatkan sumber daya manusia yang diharapkan oleh suatu organisasi agar memberikan andil yang positif terhadap semua kegiatan organisasi dalam mencapai tujuannya, setiap pegawai diharapkan memiliki motivasi kerja yang tinggi sehingga nantinya akan meningkatkan produktivitas kerja yang tinggi. Untuk memotivasi pegawai agar dapat meningkatkan produktifitas dan dapat mempunyai motivasi kerja para pegawai dibutuhkan sebuah reward. Terdapat pegawai yang termotivasi kerjanya jika diberi sebuah penghargaan dari atasan atau pimpinan. Namun juga ada pegawai yang tidak terpengaruh dengan adanya reward namun mereka akan termotivasi setelah mendapat sebuah punishment yang telah melakukan kesalahan ringan maupun berat.

\section{c. Pengaruh Kompetensi dan Motivasi Kerja terhadap Kualitas Laporan Keuangan}

Berdasarkan hasil pengujian hipotesis menunjukkan bahwa nilai signifikansi 0,001 lebih kecil dari $\alpha=0,05$ atau $F_{\text {hitung }}>F_{\text {tabel }}(11,727>3,49)$. Hal ini dapat disimpulkan bahwa variabel kompetensi dan motivasi kerja berpengaruh secara simultan terhadap kualitas laporan keuangan. Berdasarkan pengujian koefisien determinasi pengaruh yang diberikan oleh kompetensi dan motivasi kerja terhadap kualitas laporan keuangan adalah $58 \%$. Hal

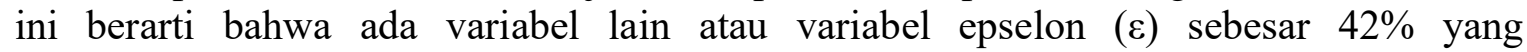
mempengaruhi variabel Y namun tidak diukur dalam penelitian ini.

Berdasarkan jawaban responden, indikator yang paling dominan dalam kualitas laporan keuangan yaitu indikator relevan 4,37. Sedangkan indikator lainnya yaitu andal dan dapat dibandingkan 4,30 serta indikator dapat dipahami 4,28. Hal ini dapat dilihat dari ratarata skor tanggapan responden terhadap item ini yang berada pada kategori sangat baik. Untuk menghasilkan laporan keuangan yang berkualitas, peran dalam menyusun laporan 
keuangan menjadi sangat penting. Penyusunan laporan keuangan hendaknya memiliki kompotensi yang memadai dalam menyusun laporan keuangan, untuk menyediakan informasi mengenai potensi pemerintah daerah untuk membiayai penyelenggaraan kegiatan pemerintah dan menyediakan informasi yang berguna untuk mengevaluasi kemampuan entitas pelaporan dalam mendanai aktivitasnya.

Seseorang yang memiliki kompetensi akan bekerja dengan pengetahuan dan keterampilannya sehingga dapat bekerja dengan mudah, cepat, intuitif, dan dengan pengalamannya bisa meminimalisir kesalahan. Kompetensi pengetahuan dan keterampilan cenderung lebih mudah untuk dikembangkan dengan adanya pendidikan dan pelatihan. Apabila sumber daya manusia yang melaksanakan sistem akuntansi tidak memiliki keahlian dibidangnya, maka akan menimbulkan hambatan dalam proses pelaksanan fungsi akuntansi. Hal ini menunjukkan bahwa kemampuan sumber daya manusia yang baik, akan meningkatkan kualitas laporan keuangan pemerintah yang dihasilkan.

\section{Kesimpulan}

\section{KESIMPULAN DAN SARAN}

Berdasarkan hasil penelitian dan pembahasan mengenai pengaruh kompetensi dan motivasi kerja terhadap kualitas laporan keuangan maka dapat disimpulkan sebagai berikut:

1. Hipotesis pertama $\left(\mathrm{H}_{1}\right)$ diterima dan disimpulkan bahwa kompetensi berpengaruh positif dan signifikan terhadap kualitas laporan keuangan Badan Keuangan dan Aset Daerah Kabupaten Muna dengan ditunjukkan oleh nilai signifikan 0,003 lebih kecil dari $\alpha=0,05$ atau $t_{\text {hitung }}>t_{\text {tabel }}(3,402>2,110)$.

2. Hipotesis kedua $\left(\mathrm{H}_{2}\right)$ diterima dan disimpulkan bahwa motivasi Kerja berpengaruh positif dan signifikan terhadap kualitas laporan keuangan Badan Keuangan dan Aset Daerah Kabupaten Muna dengan ditunjukkan oleh nilai signifikan 0,003 lebih kecil dari $\alpha=0,05$ atau thitung $>t_{\text {tabel }}(3,517>2,110)$.

3. Hipotesis ketiga $\left(\mathrm{H}_{3}\right)$ diterima dan disimpulkan bahwa kompetensi dan motivasi kerja berpengaruh positif dan signifikan terhadap kualitas laporan keuangan Badan Keuangan dan Aset Daerah dengan ditunjukkan oleh nilai signifikan 0,001 lebih kecil dari $\alpha=0,05$

\section{Implikasi} atau $F_{\text {hitung }}>F_{\text {tabel }}(11,727>3,49)$.

Berdasarkan kesimpulan diatas, menunjukkan bahwa kompetensi dan motivasi kerja berpengaruh terhadap kualitas laporan keuangan. Untuk menghasilkan laporan keuangan yang berkualitas, peran dalam menyusun laporan keuangan menjadi sangat penting. Penyusunan laporan keuangan hendaknya memiliki kompotensi yang memadai dalam menyusun laporan keuangan. Sumber daya manusia yang berkompeten adalah yang mempunyai latar belakang akuntansi sehingga mampu memahami logika akuntansi dengan baik atau paling tidak memiliki kemauan untuk terus belajar dan mengasah kemampuan di bidang akuntansi. Disamping itu sumber daya manusia yang kompeten harus memiliki pengalaman di bidang keuangan dan sering mengikuti pelatihan. Karena kegagalan dalam memahami dan menerapkan logika akuntansi akan berdampak pada ketidaksesuaian laporan keuangan dengan standar yang ditetapkan pemerintah. Untuk mendapatkan sumber daya manusia yang diharapkan oleh suatu organisasi agar memberikan andil yang positif terhadap semua kegiatan organisasi dalam mencapai tujuannya, setiap pegawai diharapkan memiliki motivasi kerja yang tinggi sehingga nantinya akan meningkatkan produktivitas kerja yang tinggi. 


\section{Keterbatasan}

Penelitian ini memiliki beberapa keterbatasan yang mungkin dapat melemahkan hasilnya. Beberapa keterbatasan dalam penelitian ini antara lain sebagai berikut :

1. Variabel yang mempengaruhi kualitas laporan keuangan pada penelitian ini terbatas pada faktor internal yaitu kompetensi dan motivasi kerja.

2. Ruang lingkup penelitian ini hanya dilakukan di lingkup badan keuangan dan aset daerah kabupaten muna sehingga hasil penelitian ini terbatas generalisasinya.

\section{Rekomendasi}

Saran yang diajukan oleh penulis berdasarkan kesimpulan dan hasil penelitian adalah sebagai berikut :

1. Kompetensi dan motivasi kerja pada BKAD perlu ditingkatkan dimana pimpinan dapat memberikan perhatian khusus, terhadap variabel-variabel tersebut, dan memberikan kesempatan pengembangan kompetensi diri melalui pendidikan dan diikuti diklat penyusunan laporan keuangan agar setiap pegawai dapat mengelola dan menghasilkan laporan keuangan yang berkualitas.

2. Penelitian ini hanya berfokus pada dua variabel saja, sehingga diharapkan peneliti selanjutnya untuk menguji variabel independen lain yang berpengaruh terhadap kualitas laporan keuangan misalnya latar belakang pendidikan, pengalaman kerja aparatur, maupun peran internal auditor yang dianggap memiliki pengaruh terhadap kualitas laporan keuangan.

\section{DAFTAR PUSTAKA}

Achmad, S Ruky. 2006. Sistem Manajemen Kinerja, Jakarta: PT. Bumi Aksara.

Ghozali, I. 2005. Model Persamaan Struktural, Semarang: UNDIP.

Gultom, Henny E.M. 2016. Pengaruh Kompetensi Dan Beban Kerja Operator Sistem Akuntansi Instansi (SAI) Terhadap Kualitas Penyajian Laporan Keuangan Pada Kantor Wilayah Kementerian Hukum Dan Hak Asasi Manusia Provinsi Lampung. Dalam Skripsi. Universitas Lampung.

Hasibuan, Malayu S.P. 2006. Manajemen Sumber Daya Manusia, Jakarta: PT Bumi Aksara.

Husein, Umar. 2009. Metode Penelitian untuk Skripsi dan Tesis Bisnis (Edisi kedua), Jakarta: Rajagrafindo Persada.

Hutapea, Parulian dan Nurianna Thoha, 2008. Kompetensi Plus : Teori, Desain, Kasus dan penerapan untuk Organisasi yang Dinamis, Jakarta: Gramedia Pustaka.

Ikatan Akuntan Indonesia. 2009. Standar Akuntansi Keuangan. PSAK No. 12. Penyajian Laporan Keuangan. Jakarta: Salemba 4.

Kuncoro. Mudrajad. 2009. Metode Riset untuk Bisnis dan Ekonomi, Jakarta: Erlangga.

Mahmudi. 2010. Manajemen Keuangan Daerah, Jakarta: Erlangga.

Mangkunegara, A. A. Anwar Prabu. 2017. Manajemen Sumber Daya Manusia Perusahaan. Bandung : PT Remaja Rosdakarya

Margalina, Ela. 2013. Pengaruh Kompetensi Dan Motivasi Kerja PUMK Universitas Pendidikan Indonesia Terhadap Kualitas Informasi Laporan Keuangan. Dalam Skripsi. Universitas Pendidikan Indonesia.

Mardiasmo. 2005. Akuntansi Sektor Publik, Yogyakarta: Andi.

Moeheriono. 2010. Pengukuran Kinerja Berbasis Kompotensi, Surabaya: Ghalia Indonesia. Nugroho, Bambang. 2006. Reward dan Punishment. Bulletin Cipta Karya, Departemen Pekerjaan Umum Edisi No 6/IV/Juni 2006 
Putri, Atikah F. 2014. Pengaruh Kompetensi Sumber Daya Manusia, Sistem Pengendalian Intern, dan Motivasi Kerja Terhadap Kualitas Laporan Keuangan (Studi Pada Satuan Kerja Perangkat Daerah Kota Bengkulu). Dalam Skripsi. Universitas Bengkulu.

Peraturan Pemerintah Nomor 71 Tahun 2010 tentang Standar Akuntansi Pemerintahan.

Sedarmayanti. 2008. Sumber Daya Manusia dan Produktivitas kerja, Bandung: CV. Mandar Maju.

Siagian, Sondang P. 2006. Sistem Informasi Manajemen, Jakarta: PT. Bumi Aksara.

Singgih, Santoso. 2002. SPSS Versi 11.5, Cetakan Kedua Jakarta: Gramedia.

Solimun, Adji Achmad Rinaldo dan Samingun Handoyo. 2017. Perancangan dan Pengujian Kuisioner Serta Transformasi Skor Menjadi Skala Berbasis MSI, SRI dan Rasch Model. Malang: Program Studi Statistika Jurusan Matematika Fakultas Matematika dan Ilmu Pengetahuan Alam Universitas Brawijaya.

Sugiyono. 2016. Memahami Penelitian Kualitatif, Bandung: CV. Alfabeta.

Uma, Sekaran. 2009. Metodologi Penelitian Untuk Bisnis, Jakarta: Salemba Empat.

Wibowo. 2012. Manajemen Kinerja (Edisi ketiga), Jakarta: Rajawali Pers. 